\title{
CONTENT ANALYSIS ON THE GRADUATE THESES DONE ABOUT FLIPPED CLASSROOM MODEL IN TURKEY
}

\author{
Dr. Omer NAYCI \\ ORCID: 0000-0002-6087-6456 \\ Child Development Programme \\ Sirnak University \\ Sirnak, TURKEY
}

Received: 22/06/2020 Accepted: 20/11/2020

\begin{abstract}
In this research, it is aimed to examine the graduate theses done about flipped classroom model in Turkey according to some variables. The data of this descriptive study which was conducted by a qualitative research approach was obtained from 105 master's and doctoral theses accessed from CoHE National Thesis Center database. The data were collected through document analysis and the data were analyzed by content analysis technique. According to the findings, it is determined that the theses were mostly done in 2019, most of the theses were made at Gazi University, the number of master's theses was more numerous, the studies conducted to examine the effect of flipped classroom model applications on various variables predominate, the model is mostly called as "Flipped classroom model" as in this study and mostly preferred in foreign language education, and in the part where the model is applied at home the most preferred online software is Edmodo. In addition, it was determined that mostly mixed methods were preferred as the research method, university students as sample group, interview form/questions as data collection tool, and "t test" in data analysis. At the end of the research, suggestions were made for researchers and for practitioners.
\end{abstract}

Keywords: Flipped classroom model, graduate thesis, content analysis.

\section{INTRODUCTION}

Today, there is a rapid change and transformation process in information and communication technologies. In this context, many components belonging to the social structure are affected by this process. It can be said that the individual comes first among these components. It is usual to have some expectations from the individual due to his/her social role. One of these expectations is to direct the public in line with the requirements along with keeping pace with the social structure. The individual who is expected to fulfill this duty should have a number of individual and social competencies. Accordingly, the quality of the education received by the individual comes into prominence as an important element.

Innovation efforts in education should also be individual and community oriented and respond to their needs. In this context, the rapid transformation experienced in technology has also reflections on education. Especially in curriculums, development and updating activities within the framework are experienced. The starting point of the mentioned studies has been what kind of an individual, and therefore what kind of a society. Accordingly, one of the questions that arise as a priority is the question of "what should we teach" In this context, the content of the "target" element which is one of the basic elements of the curriculum changes, accordingly the content, the teaching-learning process, and assessment-evaluation which are the other elements of the curriculum also change (Demirel, 2012). Along with the question "what should we teach", an answer was sought to the question "how should we teach".

In this regard, it is seen that technology-oriented practices, tools and materials are becoming widespread in the teaching-learning process. For example; e-learning, game-based learning, augmented reality, blended learning are some of them. In addition, one of the tendencies coming forward and being subject to many studies today is the Flipped Classroom Model (FCM) (Du, 2020; Subramaniam \& Muniandy, 2019; Jdaitawi, 2019; Webb \& Doman, 2020). 
FCM is named as "Flipped Instruction" as well as "Flipped Classroom" in the literature (Seaman \& Gaines, 2013, p.25). The concept also takes place in international literature as "Inverted Classroom, Reverse Teaching, Backwards Classroom (Baker, 2000; Brown, 2012; Lage, Platt \& Treglia, 2000). Inverted is used in the meaning of "to reverse, to turn upside down, to flip" as a concept (Warren, 1999, p. 247). It is also used as "donusturulmus sinif (converted classroom)" and "tersine cevrilmis sinif (reversed classroom)" in Turkish (Demiralay \& Karatas, 2014, p.337). In addition, it can be said that it is also expressed in various ways. However, it can be said that they are essentially the same.

As a concept, FCM is a blended learning model in which the aspect of transferring and discussing the content shared in the classroom is brought to the online environment and the activities expected to be carried out in the home environment are carried out to the classroom under the guidance of a teacher (Demiralay \& Karatas, 2014, p.336). In the literature, it has been subject to many researches both experimentally and conceptually and its effectiveness has been started to be tested for different disciplines (Bursa \& Cengelci Kose, 2020; Leo \& Puzio, 2016; Ritzhaupt, \& Sommer, 2018).

By the information and communication technologies becoming widespread in our lives, many new studies on FCM have been conducted in our country even in the last years (Akdeniz, 2019; Aydemir, 2019; Bolatli \& Korucu, 2020; Calici, 2019; Demir, 2020; Dincer, 2020; Gokdemir \& Gazel, 2019; Kaman, 2020; Nacaroglu, 2020; Ozaras Oz, 2019; Ozdemir, 2019; Secilmisoglu, 2019; Sogut, 2019; Sogut and Polat, 2020; Sik, 2019; Tekin, 2020; Tulay, 2019). When the literature is analysed, it was seen that especially the impact of FCM on various learning outcomes was focused in the studies (Bursa, 2019; Cakir \& Yaman, 2018; Karagoz, 2019; Kocak, 2019; Sahin, 2019; Topan, 2019). In addition, some studies aiming to describe the situation related to the practices of the model also attract the attention (Cevikbas, 2018; Demiralay Yigit, 2014; Nacaroglu, 2020). Besides, there are studies examining the effectiveness of FCM practices integrated with different variables such as game, discussion etc. (Bolatli \& Korucu, 2020; Cukurbasi, 2016; Fidan, 2019; Yilmaz, 2019). Along with these studies, it was also seen that there are some studies making design, practice and evaluation regarding FCM (Donmez, 2017; Ekmekci, 2014; Okmen, 2020).

In addition, there are studies examining the studies on FCM under a single roof (Aydin \& Demirer, 2017; Cakiroglu \& Ozturk, 2016; Kokoc \& Altun, 2014; Ozbay \& Sarica, 2019; Yildiz, Sarsar \& Ates Cobanoglu, 2017), but it is considered that there is a need also for a study on the graduate theses carried out on FCM. As a matter of fact, graduate theses shed light on many future scientific studies to be conducted thematically and methodologically. From this point of view, it was aimed to determine the tendencies by examining the graduate theses done in Turkey about FCM according to some variables in this research.

When the graduate theses prepared in Turkey are evaluated; it was observed that besides the studies in question not having a standard conceptualization status related to the model, also a common practising process was not followed in many studies that were examined. Therefore, it is important to discuss and analyse the studies conducted in the literature as a whole in terms of establishing a standard which is both conceptual and regarding implementation process of the model. In addition, it has been tried to determine the tendencies in terms of the distribution of the tendencies related to the model by years, the university in which the study was conducted, the type of publication, the denomination of the study as concept, the purpose of the studies, the fields of study, the implications applied in the practising process, the study groups, the research methods applied, the data collection and the analysis of the data. Thus it was considered that the study will be a guide for those who are interested in the model and those who want to work on this subject in the issues such as the subject of study, the implementation form of the model and scientific research processes they will use. In this direction, in the study in which it is aimed to examine the graduate theses done about the flipped classroom model in Turkey according to certain variables, answers for the following questions were sought: accordingly as for the graduate theses done about FCM in Turkey;

1. How is their distribution according to years?

2. How is their distribution according to the universities in which they were conducted?

3. How is their distribution according to the type of publication?

4. How is their distribution according to the denomination of the FCM?

5. How is their distribution according to their objectives? 
6. How is their distribution according to the field of study in which the FCM is used?

7. How is their distribution according to the monitoring/managing/interaction tools which are used in out-of-class digital environments for practical studies related to FCM?

8. How is their distribution according to the sample group?

9. How is their distribution according to the research method?

10. How is their distribution according to the data collection tools?

11.How is their distribution according to the data analysis techniques?

\section{METHOD}

\section{Research Model}

This study is a descriptive content analysis study, because of aiming to examine graduate theses done between 2014 and 2020 in line with the determined criteria and to specify the tendency in this subject. Descriptive content analysis is the systematic studies that include the discussion of studies conducted on a particular subject and evaluation of their tendencies and research results in a descriptive dimension (Calik \& Sozbilir, 2014). In addition, the method of document analysis was applied in the collection of the data obtained in this study. Document analysis involves the analysis of written materials that contain information about the phenomenon or facts intended to be examined (Yildirim \& Simsek, 2013).

\section{Population and Sample}

The population of the study is the graduate theses done about FCM in Turkey between 2014 and April 2020. Criterion sampling which is a purposeful sampling method was used as the sample in the selection of theses. Purposeful sampling allows for in-depth research by selecting information rich situations depending on the purpose of the study (Buyukozturk, Kilic Cakmak, Akgun, Karadeniz \& Demirel, 2009, p.88). Criterion sampling method is the study of situations that meet a predetermined set of criteria (Yildirim \& Simsek, 2013). Accordingly the literature was scanned for the graduate theses done about FCM in Turkey up to the present according to certain keywords within the scope of the research and the suitable theses were included in the research.

\section{Collection of Data}

The data of the study were obtained from master's and doctoral theses (graduate theses) accessed from CoHE National Thesis Center (YOK Ulusal Tez Merkezi) database in April 2020. While determining the theses, "ters", "tersine", "yuz", "duz", "ogrenme", "sinif", "cevrilmis", "donusturulmus", "model” words and their English meanings were used in the advanced search section of the CoHE National Thesis Center database, 110 theses which are suitable for the purpose of the study were listed, and among the listed theses 5 theses were not included in the study since being unavailable for access. Finally, 105 theses were included within the scope of the research.

\section{Analysis of Data}

The data obtained were analysed by content analysis technique. The basic process in content analysis is to combine similar data within the framework of certain themes and concepts and interpret them by organizing them in a way that the reader can understand (Yildirim \& Simsek, 2013, p.259). For the analysis of the data, a graduate theses about FCM analysis form was created by the researchers. The content analysis directive used by Saban (2009) in the study was taken as a criterion in the mentioned form. For the purpose of the research, certain questions in the mentioned directive were changed. The examination form was put into its final form accordingly and the theses included in the study were analysed accordingly. The titles of the year, university, type of publication, name of the publication, purpose, field of study, monitoring/management/ interaction tools used, target group, research method, data collection tool and data analysis technique with regards to the determined criteria took place in the form. 
The analysis of the data was done according to the steps of the content analysis. These stages are coding data, finding themes, editing codes and themes, defining and interpreting the findings (Yildirim \& Simsek, 2013). Graduate theses were analysed according to these steps. Before starting the coding process, some randomly selected theses were coded with the other two encoders according to the directive in terms of the consistency of the data encoded by the first researcher.

\section{FINDINGS}

In this section, findings reached as a result of the analysis of data obtained from graduate theses done about FCM in Turkey were given place. The data are presented in graphics.

\section{Findings Regarding the Distribution of Graduate Theses according to Publication Year}

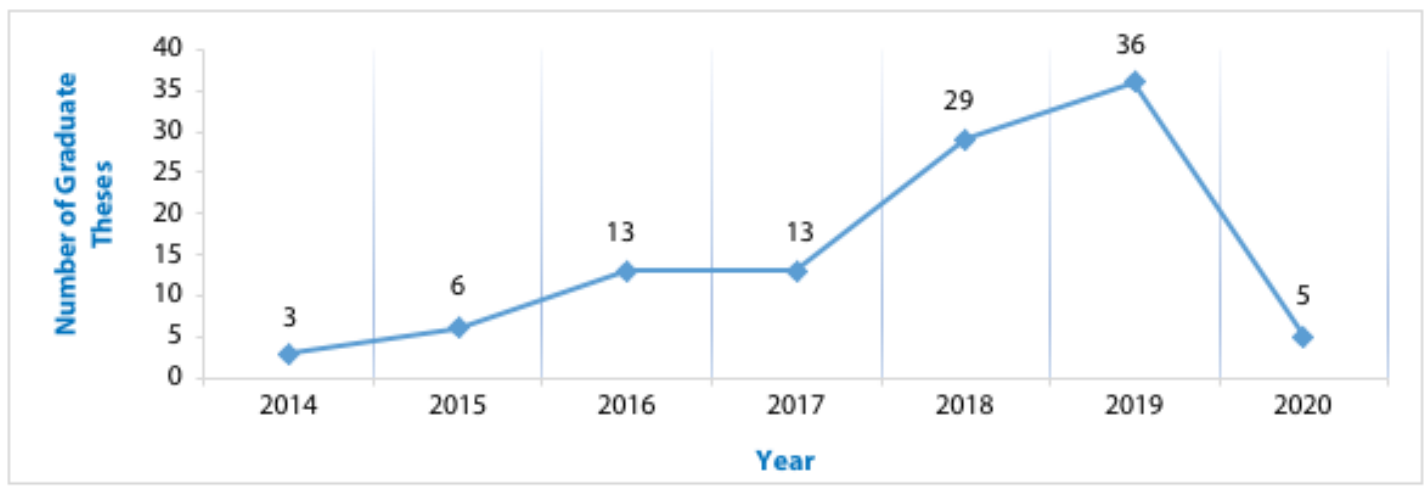

Figure 1. The distribution of graduate theses according to publication year

According to Figure 1 it is seen that the graduate thesis about FCM in Turkey started to be done in 2014, the studies on this subject has increased rapidly until today and in 2019 the number of theses has reached the highest level. 


\section{Findings Regarding the Distribution of Graduate Theses according to the Universities in Which They Were Done}

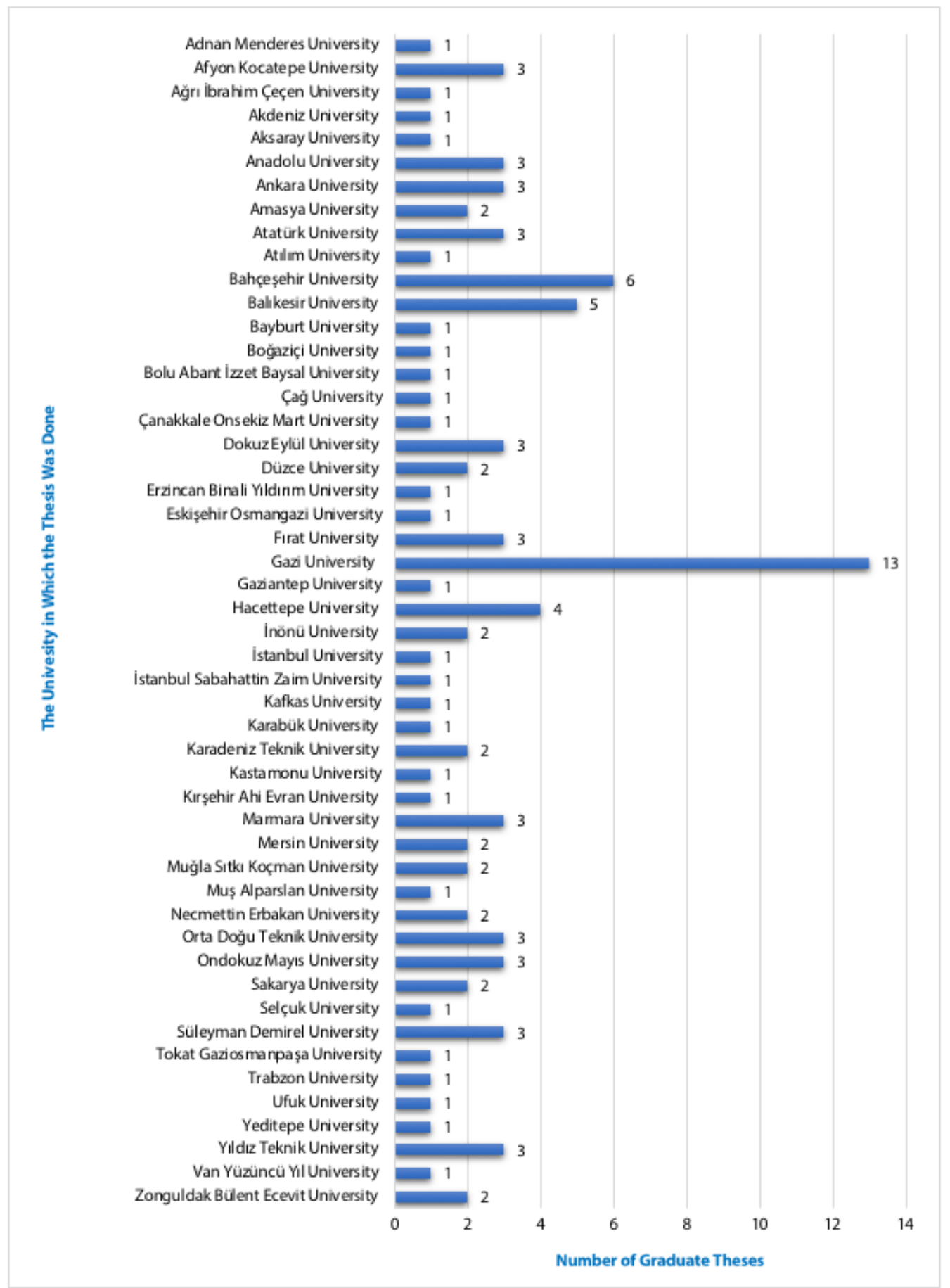

Figure 2. The distribution of graduate theses according to the universities in which they were done

When Figure 2 is examined; it is seen that graduate theses regarding FCM in Turkey was done mostly at Gazi University $(\mathrm{f}=13)$. This is followed by Bahcesehir University $(\mathrm{f}=6)$, Balikesir University $(\mathrm{f}=5)$ and Hacettepe University $(\mathrm{f}=4)$ respectively. 


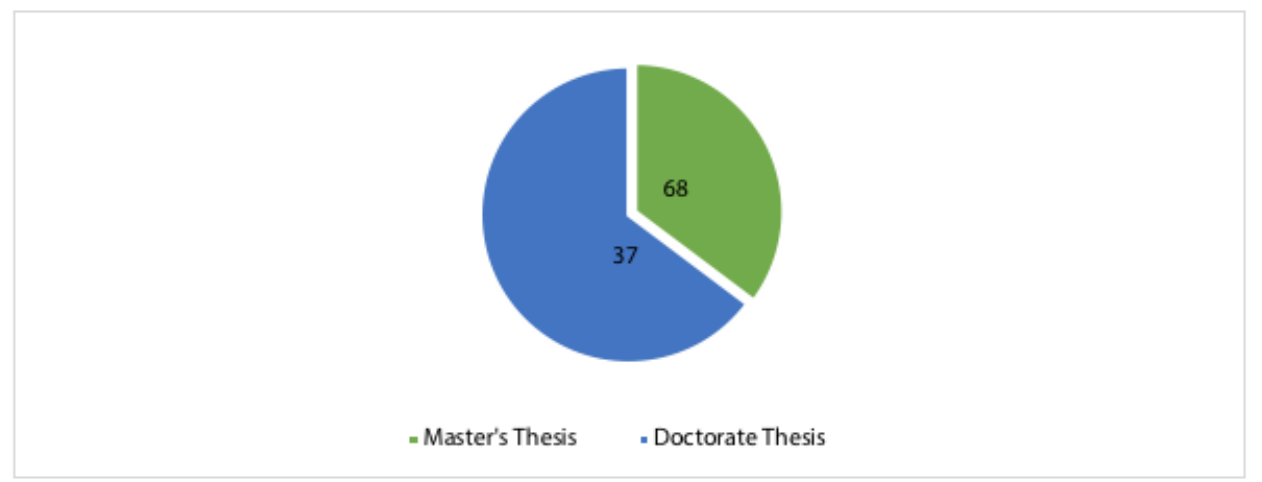

Figure 3. The distribution of graduate theses according to publication type

When the distribution of graduate theses according to publication type is examined; it is seen that 68 of the completed studies about FCM in Turkey is the master's thesis and 37 of them is doctoral thesis.

\section{Findings Regarding the Distribution of Graduate Theses according to the Denomination of the Model}

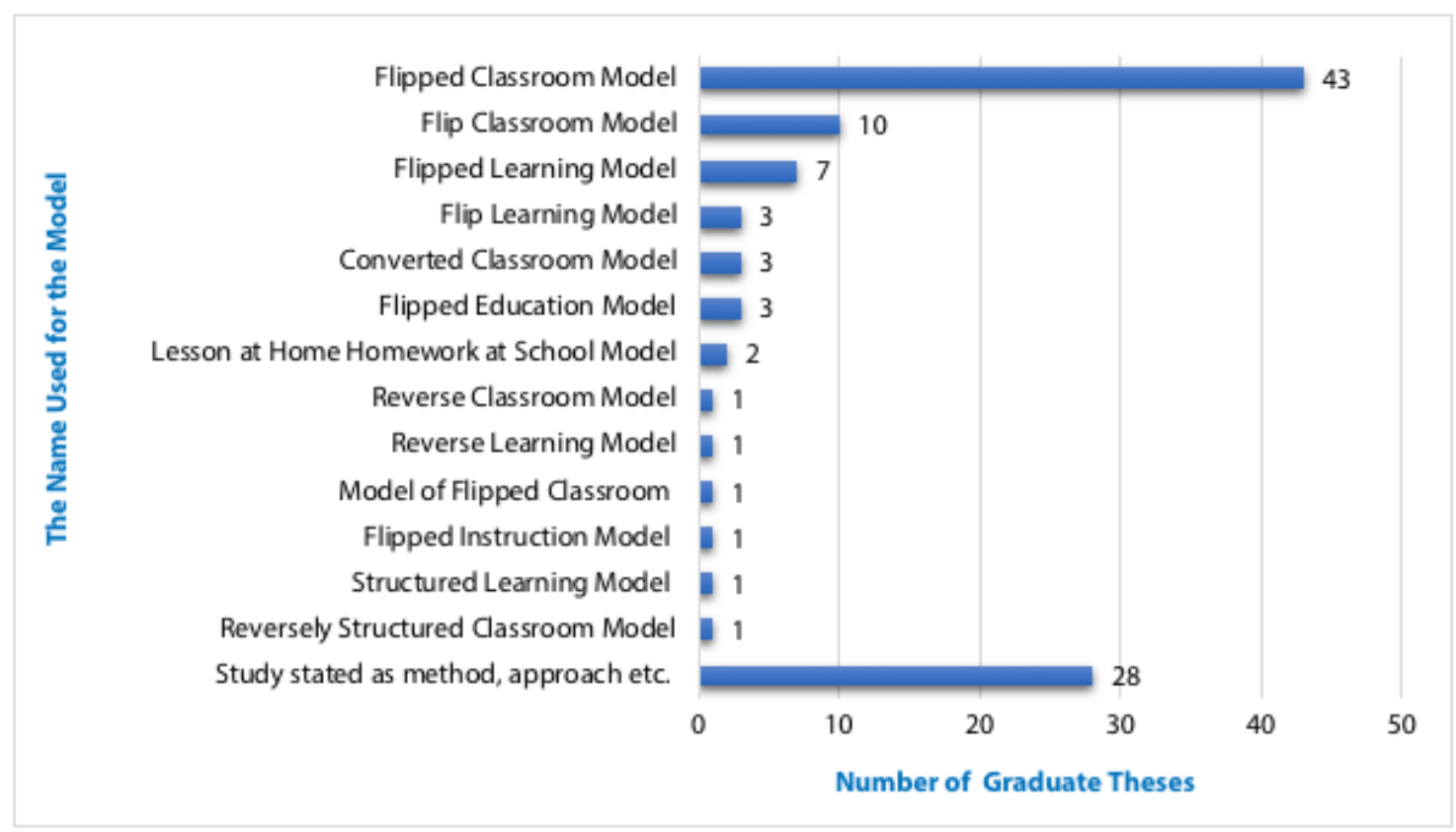

Figure 4. The distribution of graduate theses according to the denomination of the model

When Figure 4 is examined; it is seen that in the theses done about FCM in Turkey, this model is named in many different ways. While this model is mostly named as the "flipped classroom model" ( $\mathrm{f}=43$ ), it is also seen that expressions such as "flip classroom model" ( $\mathrm{f}=10)$ and "flipped learning model" ( $\mathrm{f}=7$ ) are also used. In twenty-eight studies, the mentioned model was stated as method, approach, etc. It is expressed in figures. 


\section{Findings Regarding the Distribution of Graduate Theses according to Their Purposes}

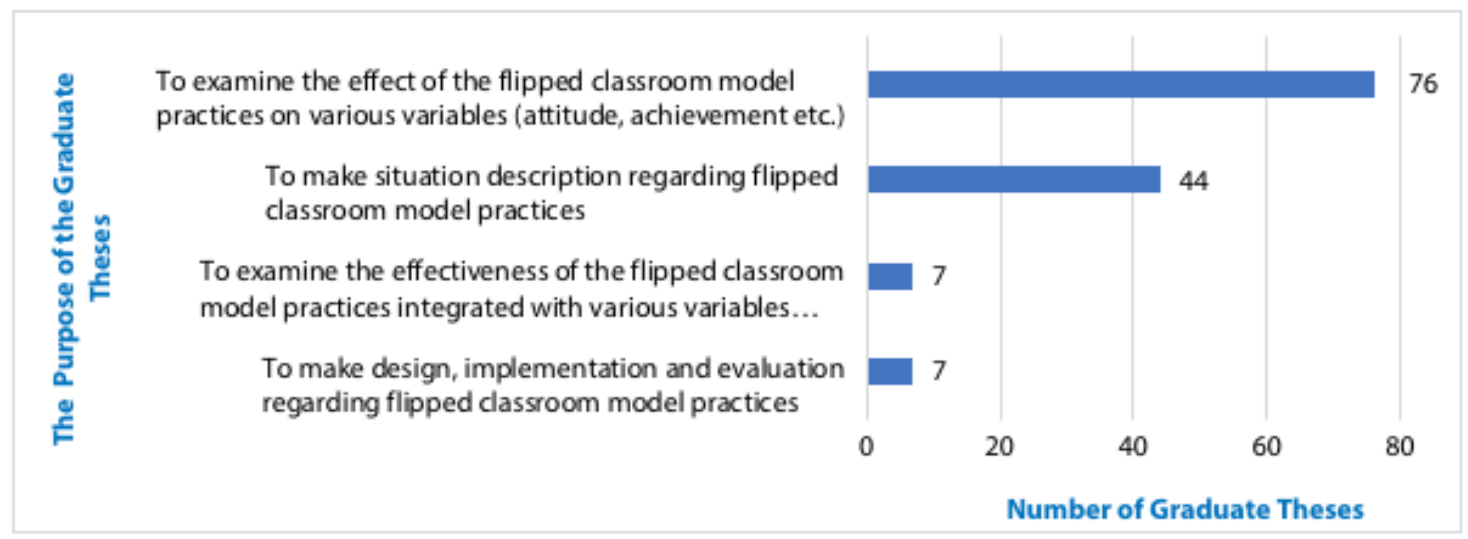

Figure 5. The distribution of graduate theses according to their purposes

When Figure 5 is examined; it is seen that most of the studies conducted about FCM in Turkey is aimed at the examination of the effect of FCM practices on various variables $(f=76)$. It is seen that these are followed by the studies ( $\mathrm{f}=44$ ) aiming to make situation description related to FCM applications. It is also observed that studies examining FCM practices integrated with various variables $(\mathrm{f}=7)$ and studies making design, implementation and evaluation $(\mathrm{f}=7)$ regarding FCM practices are conducted as well.

\section{Findings Regarding the Distribution of Graduate Theses according to the Field of Study in Which the FCM is Used}

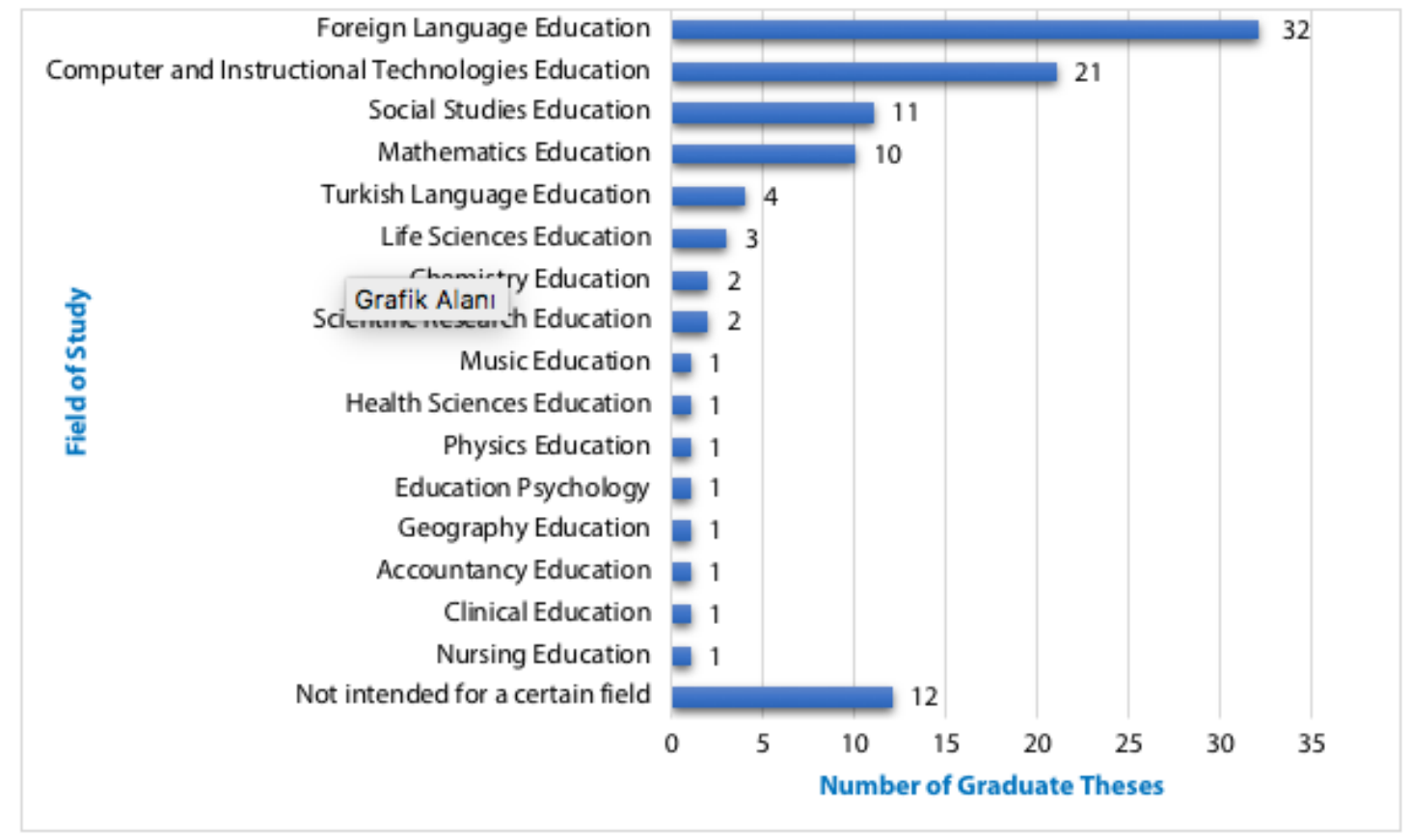

Figure 6. The distribution of graduate theses according to the field of study in which the $\mathrm{fcm}$ is used

When Figure 6 is examined, it is seen that the postgraduate theses ( $\mathrm{f}=32)$ made for the use of FCM in foreign language education are the most in number. This is followed by computer and instructional technology education ( $\mathrm{f}=21)$, social studies education $(\mathrm{f}=11)$, and mathematics education $(\mathrm{f}=10)$. In addition, it has been determined that there are also studies $(\mathrm{f}=12)$ which do not integrate FCM with a certain field. 


\section{Findings Regarding the Distribution of Graduate Theses according to the Monitoring/ Management/Interaction Tools Used in Out-of-Class Digital Environments}

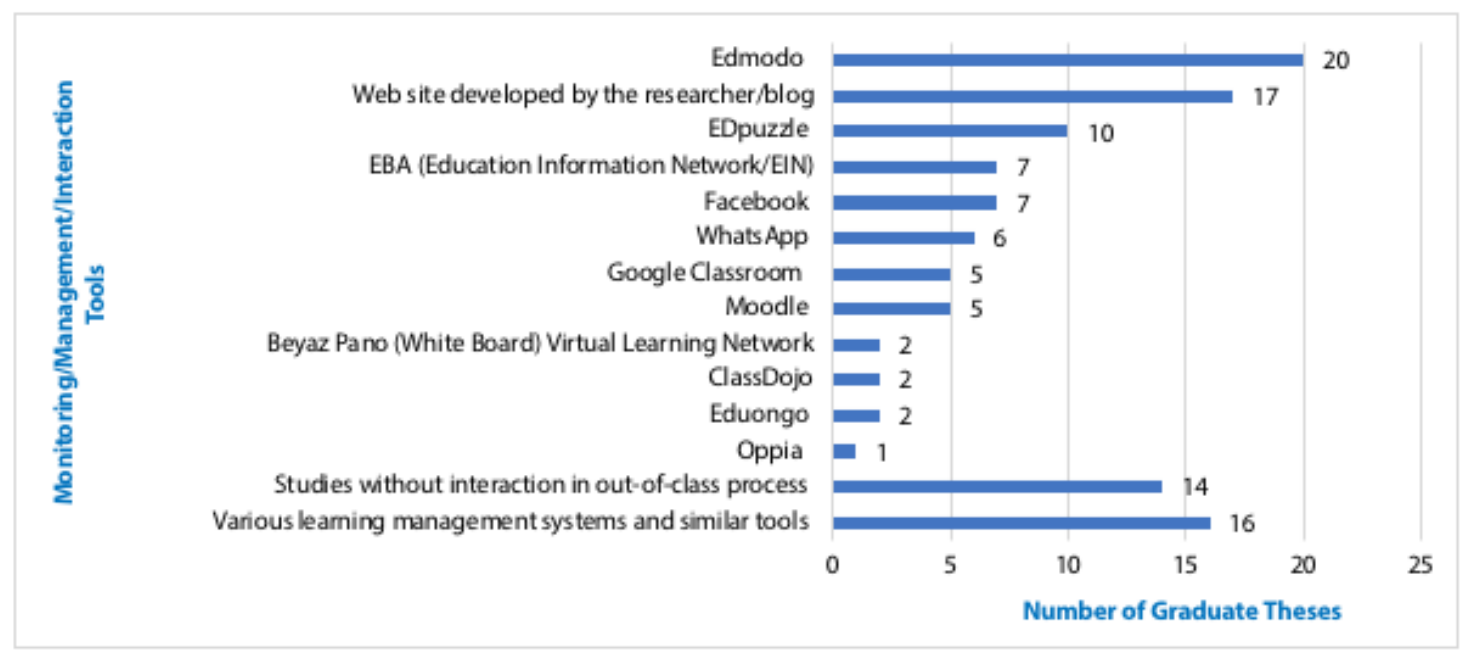

Figure 7. The distribution of graduate theses according to the monitoring/management/interaction tools used in out-of-class digital environments

When Figure 7 is examined; it is seen that Edmodo $(\mathrm{f}=20)$ is the most preffered tool as monitoring/ management/interaction tool in out-of-class digital environments used in applied studies conducted about FCM in Turkey. This is followed by tools such as the website/blog $(\mathrm{f}=17)$ which the researcher developed. Apart from this, besides various learning systems and other tools $(\mathrm{f}=16)$, there are studies without interaction in the out-of-class process $(\mathrm{f}=14)$, in other words, studies that do not include learner-instructor interaction in out-of-class learning activities. These studies are the studies in which the out-of-class process is the recording of the lecture part to any tool and the learners complete the out-of-class process from this record. Along with these, EDpuzzle ( $\mathrm{f}=10)$, EBA ( $\mathrm{f}=7)$, Facebook ( $\mathrm{f}=7)$, WhatsApp ( $\mathrm{f}=6)$, Google Classroom ( $\mathrm{f}=5)$, Moodle $(\mathrm{f}=5)$ and other tools were also used respectively.

\section{Findings Regarding the Distribution of Graduate Theses according to Sample Group}

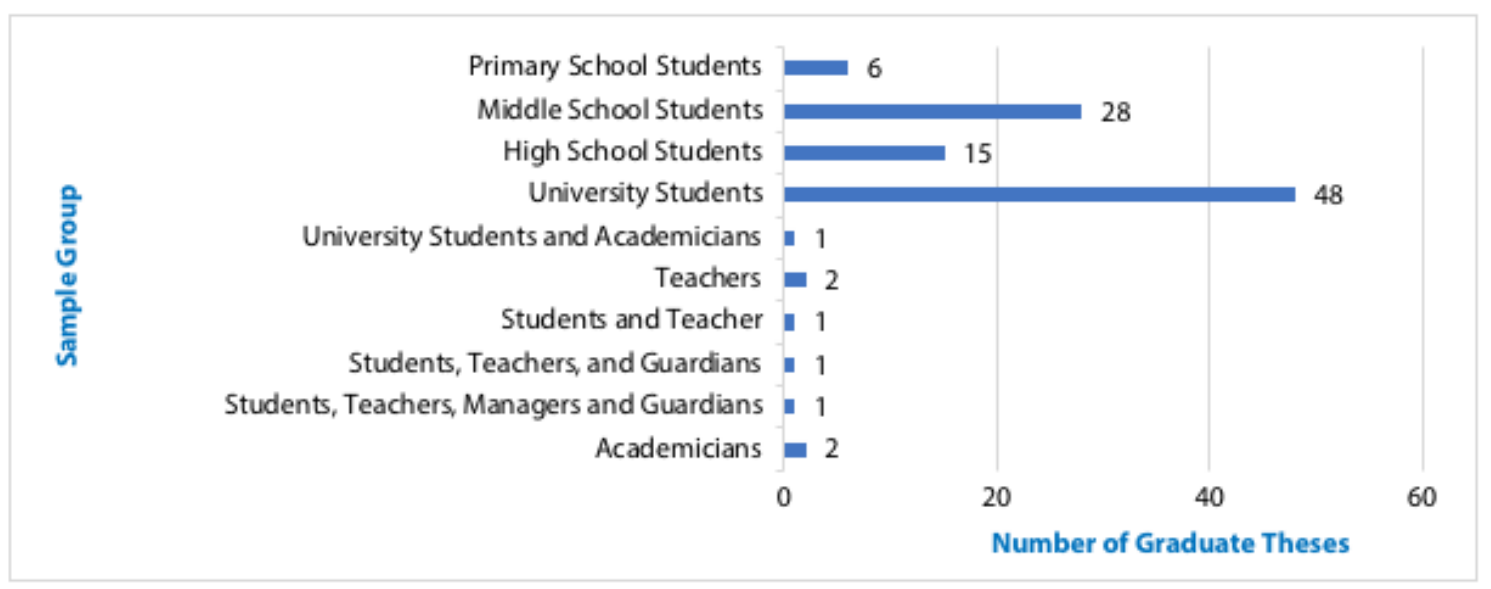

Figure 8. The distribution of graduate theses according to sample group 
When Figure 8 is examined, it is seen that mostly university students ( $\mathrm{f}=48)$ are preferred as the sample group according to graduate theses done about FCM. This is followed by middle school students $(\mathrm{f}=28)$ and high school students $(\mathrm{f}=15)$, respectively. It is also noteworthy that very few studies including teachers and academicians were conducted.

\section{Findings Regarding the Distribution of Graduate Theses according to Research Method}

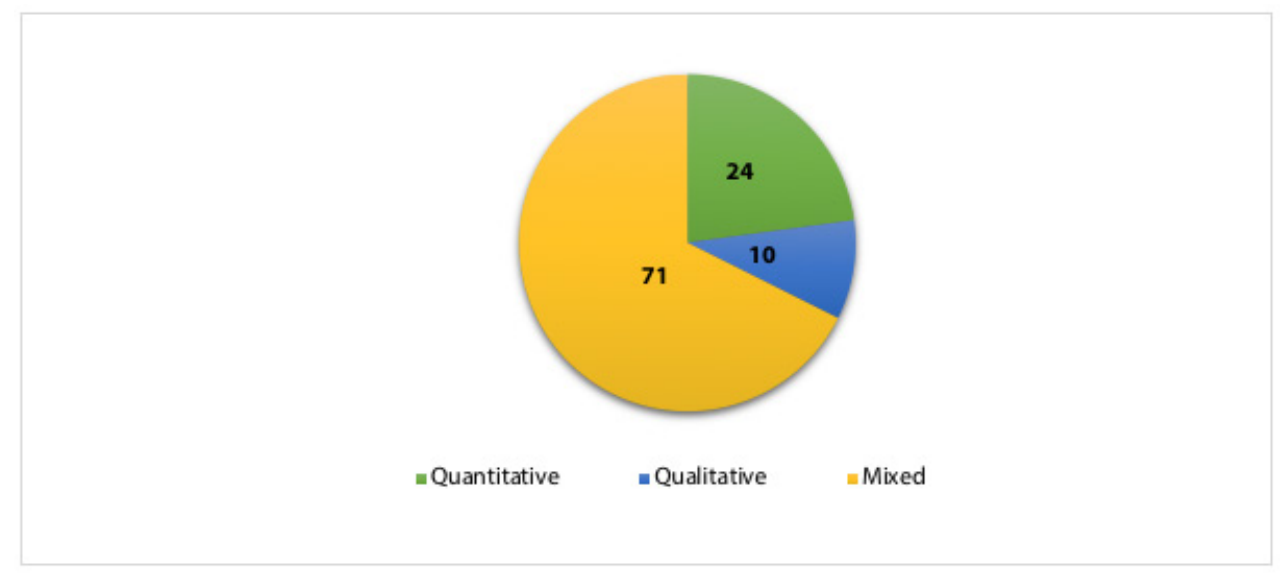

Figure 9. The distribution of graduate theses according to research method

When Figure 9 is examined; it is seen that mixed methods $(\mathrm{f}=71)$ were preferred the most as research method in graduate theses done about FCM in Turkey. This is followed by studies that prefer quantitative $(f=24)$ and qualitative $(f=10)$ methods respectively.

\section{Findings Regarding the Distribution of Graduate Theses according to Data Collection Tools}

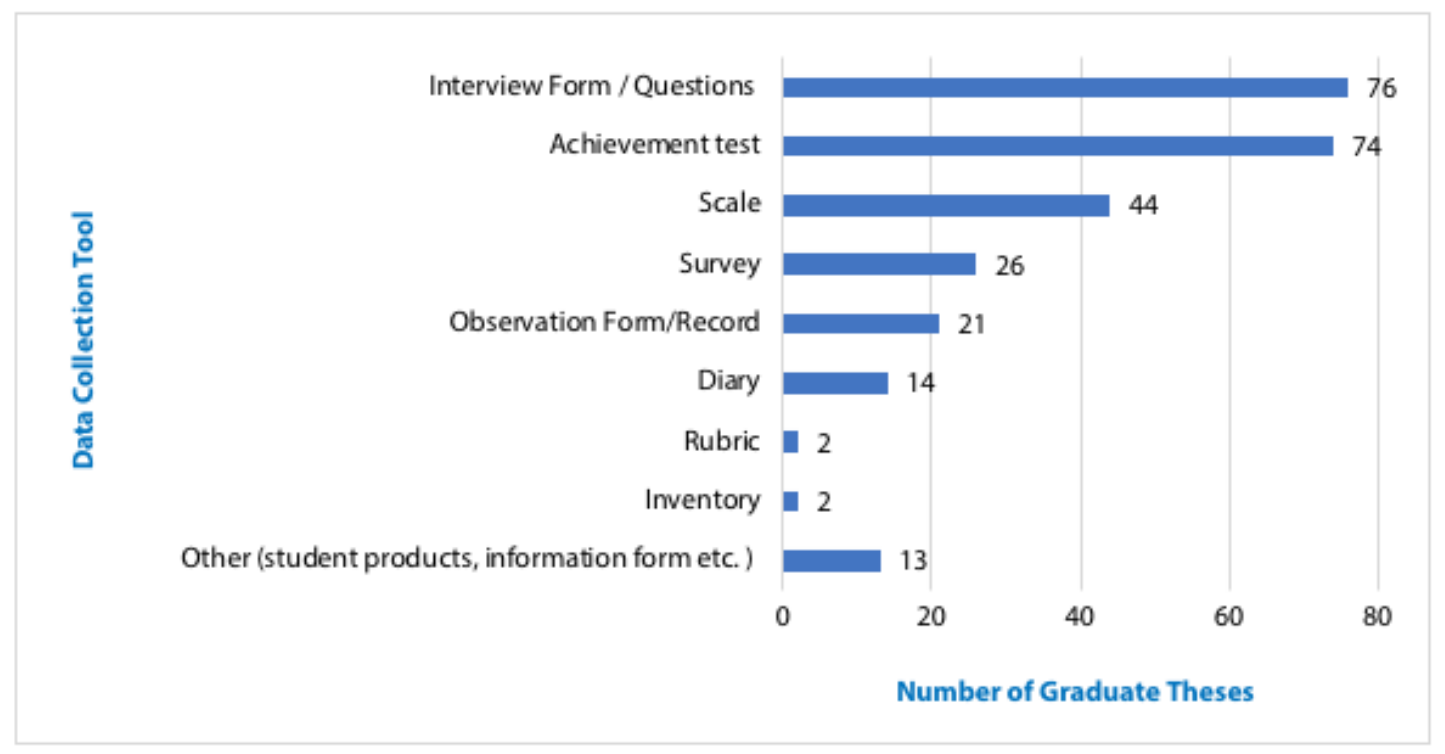

Figure 10. The distribution of graduate theses according to data collection tools 
When Figure 10 is examined; it is seen that interview form/questions ( $\mathrm{f}=76)$ are used the most as data collection tool in the studies related to FCM. Then, success test $(\mathrm{f}=74)$, scale $(\mathrm{f}=44)$, questionnaire $(\mathrm{f}=26)$, observation form/record $(\mathrm{f}=21)$, diary $(\mathrm{f}=14)$, rubric $(\mathrm{f}=2)$ and inventory $(\mathrm{f}=2)$ are preferred the most as the data collection tool in the studies on this subject.

\section{Findings Regarding the Distribution of Graduate Theses according to Data Analysis Technique}

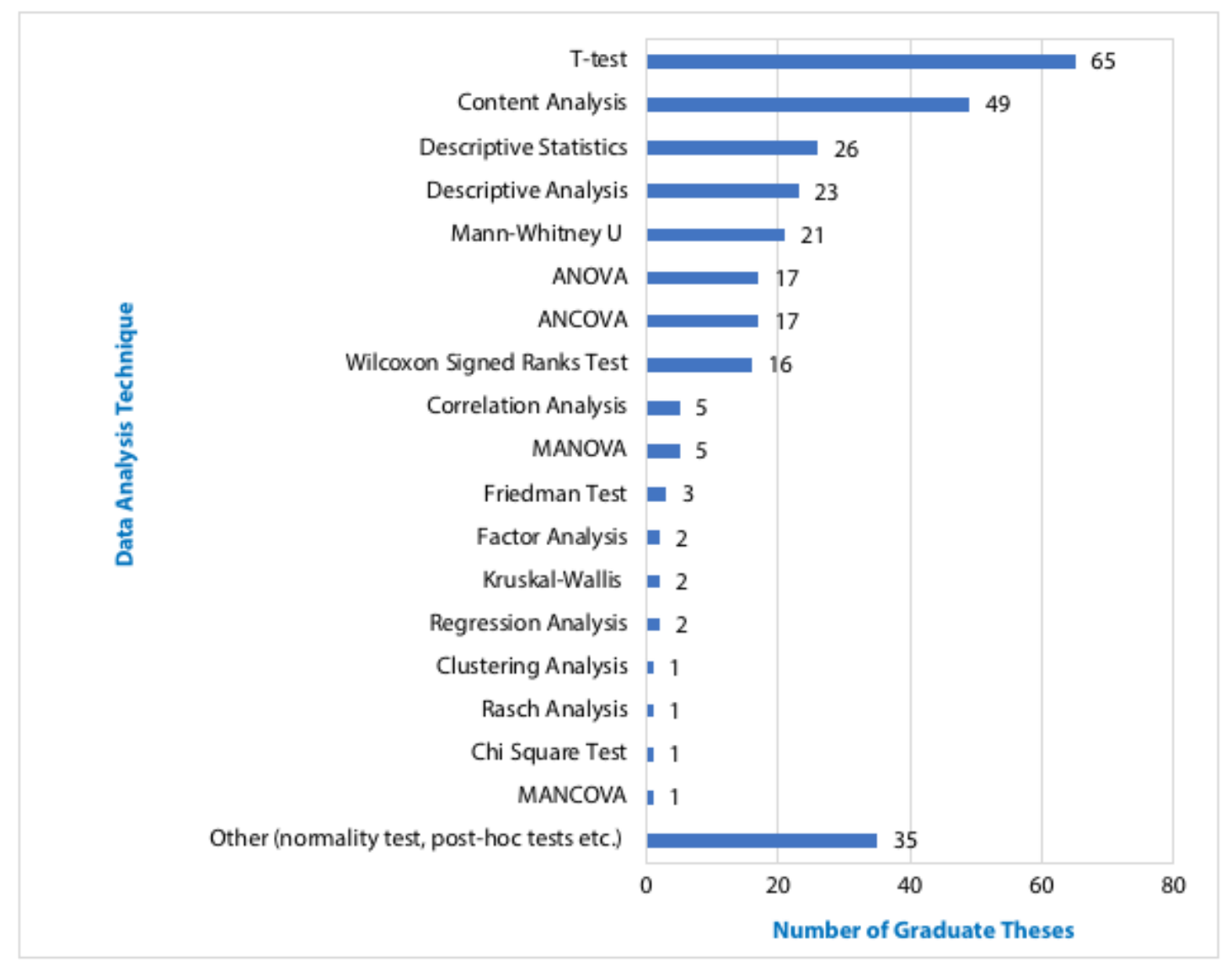

Figure 11. The distribution of graduate theses according to data analysis technique

When Figure 11 is examined, it is seen that "t-test" $(\mathrm{f}=65)$ is used the most as the data analysis technique in graduate theses done about FCM. This is followed by content analysis $(\mathrm{f}=49)$, descriptive statistics $(\mathrm{f}=26)$, descriptive analysis ( $\mathrm{f}=23)$, Mann Whitney $\mathrm{U}(\mathrm{f}=21)$, ANOVA ( $\mathrm{f}=17)$, ANCOVA ( $\mathrm{f}=17)$, Wilcoxon signed ranks test $(\mathrm{f}=16)$ and other tests.

\section{DISCUSSION, CONCLUSION AND RECOMMENDATIONS}

When the findings obtained from the study in which graduate thesis done about FCM in Turkey were examined according to certain variables and the tendencies regarding the model were tried to be specified, are evaluated; it has been observed that the distribution of graduate theses made between 2014-2020 according to the publication year differentiates. Accordingly, the theses related to the model started in 2014, while a big increase is not observed until 2017, the biggest increase was observed between 2017-2018 that followed. The year 2019 has been the year with the highest number of theses among the years included in the research. It can be said that the spread of computer-aided applications in the context of technology integration in education as in every field in recent years has an effect on the formation of a tendency related to the model. 
It has been observed that the graduate theses about FCM are done predominantly in Gazi, Bahcesehir, Balikesir and Hacettepe universities. It is considered that the reason for Gazi University being the university where the most studies on the model were conducted is because of the fact that FCM is implemented under the umbrella of computer and instructional technology education due to its subject field and the university has been conducting studies in this field for many years. In addition, when the distribution of graduate theses by type of publication is examined, it is seen that there are 68 studies at master level and 37 studies at doctorate level.

When the literature is examined, it is seen that FCM is mentioned by various names. It can be said that a standard has not yet been formed in terms of naming the model. When the distribution of the denomination of the model in graduate theses is examined; it was observed that it was mostly named as "flipped classroom model". This was followed by "flip classroom model" and "flipped learning model", respectively. Apart from this, when the Turkish literature is examined; it is seen that it was the subject of different studies with various names such as "Flipped Classroom System" (Gencer, Gurbulak \& Adiguzel, 2014), "Inverted Learning Model" (Sever, 2014), "Lesson at Home Homework at School" (Demiralay, 2014), "Flipped Classroom Method" (Turan \& Goktas, 2015), and "Reverse Education Practice" (Boyraz, 2014). As one of the reasons for the mentioned difference in the denomination of the model, it is considered that the model has not been fully clarified by the researchers in the context of the theoretical framework.

When the distribution of graduate theses related to FCM according to their purposes is examined; it has been seen that mostly there are studies examining the effect of practices related to FCM on various variables (attitude, achievement etc.). The reason for this was considered to be the fact that FCM being a new practice in the literature, eliminating the question marks regarding whether it has an effect especially on the academic achievement and attitudes of the learners is a priority. This was followed by studies in which situation descriptions related to the implementation of the model were. As for this, it can be said that besides a number of outputs of the model in terms of quantity, the views of different study groups regarding the implementation process are also considered important. Thus, a great majority of the studies was done by mixed pattern. Apart from these, there are also studies conducted for the effectiveness of FCM applications integrated with variables such as games, discussions, etc. In addition, there are studies conducted for the design, implementation and evaluation related to the implementation of the model as well. In this type of studies, it was tried to be evaluated especially how the model should be practiced in other words; which inclass and out-of-class components should be used in what way and what may their results be. Accordingly, in the study conducted by Cakiroglu and Ozturk (2016), it was specified that while "Academic Achievement" is the variable which was studied the most, "Perception, FCM Design and Implementation Principles" are frequently studied variables In addition, "Learning styles, Cognitive load, Attitude" were the least studied variables. Here, a different result has been observed in this research, especially in the context of "attitude". One of the main reasons for this is that Cakiroglu and Ozturk (2016) included theses mostly from foreign literature to their studies. Similarly, in the study conducted by Aydin and Demirer (2017), academic achievement was found to be the most examined variable.

When the distribution of graduate theses according to the field of study in which FCM was used is examined; it was seen that the model was implemented mostly in the field of foreign language education. This was followed by computer and instructional technology education. In the study of Ozbay and Sarica, (2019), it has been determined that FCM is mostly used in the field of foreign language education, supporting this finding. As it is known, the model is designed in two different ways: in-class implementations and out-ofclass online components (Baker, 2000). In addition, FCM is formed from the combination of processes that require individual interaction and out-of-class implementations that involve a computer-aided teachinglearning process (Bishop \& Verleger 2013). It is considered that the reason for studies being conducted predominantly related to this two disciplines is the curriculums of the mentioned courses being more appropriate for being taught by FCM within the context of both in-class implementations and out-of-class components of the model. Particularly, the need for computer-aided applications in the teaching-learning processes of the mentioned courses coinciding with the design and implementation processes of the model may be effective in the tendency to these disciplines. Apart from these two disciplines, it has been observed that the model is frequently used in social studies and mathematics education. In the study conducted by Aydin and Demirer (2017), it was observed that the studies were mostly in the field of mathematics and 
then in the field of foreign language education. It can be said that in both studies, the disciplines which were studied the most are common in terms of two disciplines. On the other hand, Kokoc and Altun (2014) determined in their research that studies related to the Flipped learning method are intensified in the field of health sciences.

When the distribution of the applied studies on FCM according to the monitoring/management/interaction tools used in out-of-class digital environments is examined; it was seen that the application named Edmodo was preferred the most. Edmodo which is a learning management system, meeting the requirements within the context of out-of-class online components can be shown among the reasons for it being preferred. Besides, along with sharing the content related to the subject through the mentioned application, it is possible to carry out activities such as discussion and question-answer online together with the learners by homework and file sharing. In addition to all these, both the cost and the availability of the application can be counted among the reasons for the preference of the application by the researchers. It is seen that after Edmodo, the website / blog developed by the researcher and EDpuzzle are the other preferred software or applications respectively. Ozbay and Sarica (2019) revealed that researchers mostly preferred the Moddle environments in presenting the content. Kokoc and Altun (2014), on the other hand, found in the studies they examined that there is a tendency to utilize existing technologies instead of developing environment, tools and software to be used in the learning process, supporting these findings. One of the remarkable results obtained from the research data is that in some studies there is no learner-teacher interaction in outof-class learning activities except from the mentioned tools. In other words, in some studies, out-of-class process of the learners was only in the form of conducting the study by benefiting from the record. It can be said this does not coincide with the essence of the model in the context of in-class practices (explain, expand, apply, practice) and out-of-class online components (lessons, subject discussion, quizzes) that Baker (2000) suggested related to the model. Hence, contrary to a model that has only one of the in-class or out-of-class components, this model will be fully benefited by using both implementation processes together at the same time in the context of their own subcomponents.

When the distribution of the graduate theses examined within the scope of the research according to the sample group is examined; it was seen that university students were preferred more in terms of sampling. In the study conducted by Aydin and Demirer (2017), it was seen that more studies were conducted with that group in the study in which graduate theses abroad were examined. Similarly, Ozbay and Sarica (2019) found that undergraduate students were preferred more in studies related to FCM. In their study, Kokoc and Altun (2014) determined that the majority of the studies were carried out at higher education level and mostly student performance and student perceptions were examined in order to decide on effectiveness. It is considered that these results areoriginated from the mentioned sample group; university students acting more consciously, especially in the use of the model's out-of-class online components in terms of both accessing the tools and equipments in the field of information and communication technologies and fulfilling the responsibilities expected of them.

It was seen that mixed method was preferred the most as the research method in the graduate theses done about FCM in Turkey. This was followed by qualitative and then quantitative research methods respectively. Due to the fact that the model has more than one component and implementation process, not only obtaining the data related to the variables such as academic achievement, attitude, but also obtaining the opinions of the study group regarding the model is quite important with regards to the evaluation of the model as a whole. Thus, it can be said that it is to the purpose to choose mixed methods in the research process. However, in certain studies similar to this in the literature, quantitative research methods were used more (Aydin \& Demirer, 2017; Kokoc \& Altun, 2014; Ozbay \& Sarica, 2019). In addition, in the study conducted by Cakiroglu and Ozturk (2016), it was observed that experimental researches were preferred more and mixed method researches followed. Therefore, it is concluded that the researches that examine the researches abroad and the results obtained from these researches do not coincide with each other in terms of the preferred research method. Yildiz, Sarsar and Ates Cobanoglu (2017), on the other hand, revealed that qualitative methods were preferred the most in the studies related to the converted classroom.

When the distribution of graduate theses according to data collection tools is examined; it was seen that interview form and achievement test were preferred the most as the data collection tool. It can be said that this corresponds to the nature of the research methods used in theses. It can be stated that mentioned two 
data collection tools were used in the studies in which both academic achievement and participants' opinions regarding the model should be obtained. Hence, it is thought that these data collection tools are used more. Other frequently used data collection tools were found to be scale, survey and observation form/record.

When the data analysis techniques used in graduate theses are examined; "t test" and "content analysis" were the most used analysis techniques. It can be said that " $t$ test" was preferred because of being one of the most suitable techniques for testing academic achievement. In addition, in studies where both mixed and qualitative research methods are used, content analysis which is frequently used in the analysis of the qualitative data related to the model and one of the most appropriate analysis techniques is expected to be preferred. Besides, it is seen that the most frequently applied data analysis types were descriptive statistics, descriptive analysis and Mann-Whitney U.

Consequently, when the graduate theses done about FCM are examined; it can be said that FCM is started to be the subject of many researches depending on the rapid change and transformation process in the information and communication technologies. Since it is a current issue, it has been seen that there is no standardization in the conceptual dimension of the model. It can be said that the studies on the model in question mostly focus on academic achievement and attitude. And this is important in terms of the popularization and acceptability of the model in the literature. Through such studies, in addition to measuring the effect of the model on the teaching-learning process, a unity in the implementation can also be achieved by various and rich technology-based tools in terms of the model. Although its impact has been measured in terms of some disciplines and fields in the literature on FCM, there are many disciplines and areas whose impact has not yet been measured. Therefore, this deficiency should also be eliminated in terms of this model being widespread and acceptable. Conducting similar studies in this process can be a guide for future studies and can contribute to the conduct of studies with improved standards in this regard. With this study, it is tried to establish the general framework and contribute to the creation of tendency to the variables that are less studied.

Based on the results of the research; the following recommendations can be made to the researchers who will study on the model;

- This study is limited to the graduate thesis made about FCM in Turkey between 2014-2020. In future studies, graduate theses made nationally and internationally can be researched comparatively. Thus, by comparing different and similar phenomena, it can be contributed to the formation of standards in terms of different dimensions related to the model.

- By conducting research on both the conceptual and theoretical dimensions of the model, the formation of standards can be ensured in terms of both denomination and implementation dimension.

- Less studied subjects and disciplines can be studied contrary to the similar researches to previous researches.

- The reasons for preferring the monitoring/management/interaction tools used in out-of-class digital environments of the conducted studies and the ideal tools for the model can be researched.

- In order to spread the model and prove its feasibility, studies can be conducted on the problem and solution suggestions by working with the least studied sample groups. 


\section{BIODATA and CONTACT ADDRESSES of AUTHOR}

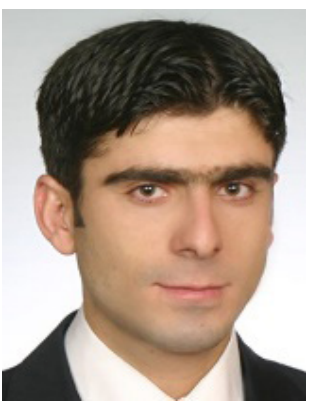

Dr. Omer NAYCI received his Bachelor's degree from Ankara University Faculty of Educational Sciences, his Master's degree from Ankara University Educational Sciences Institute and his $\mathrm{PhD}$ from the same university. After working as a teacher for four years following his undergraduate education, he started to work as an academician at the university and still works as a lecturer at Sirnak University. $\mathrm{He}$ studies on the subjects of teacher education, education programs and training, drama and educational technologies.

\section{Omer NAYCI}

Child Development Programm,

Address: Sirnak University, Sirnak Vocational College, 73000, Sirnak, Turkey,

Phone: +90 4862168005

E-mail: nayciomer@gmail.com

\section{REFERENCES}

Akdeniz, E. (2019). Ters yuz sinif modelinin akademik basari, tutum ve kalicilik uzerine etkisi (Unpublished master's thesis). Necmettin Erbakan Universitesi, Konya.

Aydemir, E. (2019). Ters-yuz edilmis sinif ortaminin Ingilizce ogretmenligi bolumu'nde okuyan ogretmen adaylarinin ileri okuma ve yazma becerileri, ogrenmede oz-duzenleme becerileri ve sinif ici etkilesimleri uzerine etkisi (Unpublished doctoral dissertation). Bahcesehir Universitesi, Istanbul.

Aydin, B. \& Demirer, V. (2017). Ters yuz sinif modeli cercevesinde gerceklestirilmis calismalara bir bakis: Icerik analizi. Egitim Teknolojisi Kuram ve Uygulama, 7(1), 57-82. doi: 10.17943/etku.288488

Baker, J. W. (2000). The 'Classroom Flip': Using web course management tools to become the guide by the side. In 11th international conference on college teaching and learning, 23 June 2000 (pp. 9-17). Jacksonville, Florida Community College at Jacksonville.

Bishop, J.L. \& Verleger, M.A. (2013). The flipped classrom: a survey of the research. In 120th American Society for Engineering Education (ASEE) National Conference Proceedings, 23-26 June 2013 (pp. 20-26). Atlanta, GA.

Bolatli, Z. \& Korucu, A.T. (2020). Determining the academic achievement of students who use flipped classroom method supported by a mobile application and their views on collaborative learning. Bartin University Journal of Faculty of Education, 9(2), 229-251. doi: 10.14686/buefad.631835

Boyraz, S. (2014). Ingilizce ogretiminde tersine egitim uygulamasinin degerlendirilmesi (Unpublished master's thesis). Afyon Kocatepe Universitesi, Ankara.

Brown, A. F. (2012). A phenomenological study of undergraduate instructors using the inverted or flipped classroom model. Doctoral dissertation, Pepperdine University. Retrieved 22.04.2020, from https://search. proquest.com/openview/f8e8165f517566525358f49bbc0198ca/1?pq-origsite=gscholar\&cbl=18 750\&diss $=\mathrm{y}$

Bursa, S. (2019). Sosyal bilgiler dersinde ters-yuz sinif uygulamalarinin ogrencilerin akademik basari ve sorumluluk duzeylerine etkisi (Unpublished doctoral dissertation). Anadolu Universitesi, Eskisehir.

Bursa, S. \& Cengelci Kose, T. (2020). The effect of flipped classroom practices on students' academic achievement and responsibility levels in social studies course. Turkish Online Journal of Distance Education, 21(4), 143-159. doi:10.17718/tojde.803390

Buyukozturk, S., Kilic Cakmak, E., Akgun, O.E., Karadeniz, S., \& Demirel, F. (2009). Bilimsel arastirma yontemleri (3th ed.). Ankara: Pegem Akademi Yayinevi. 
Cakir, E. \& Yaman, S. (2018). Ters yuz sinif modelinin ogrencilerin fen basarisi ve bilgisayarca dusunme becerileri uzerine etkisi. GEFAD, 38 (1), 75-99.

Cakiroglu, U. \& Ozturk, M. (2016). Ters-yuz sinif modelinin uygulama egilimlerinin incelenmesi. In 10th Internatonal Computer \& Instructonal Technologes Symposum (pp.167-179). Rize, Turkey.

Calik, M. \& Sozbilir, M. (2014). Icerik analizinin parametreleri. Egitim ve Bilim, 39(174), 33-38. doi:10.15390/EB.2014.3412

Calici, M. A. (2019). Ters yuz sinif yonteminin 6. sinif ogrencilerinin dinledigini anlama becerisine etkisi (Unpublished master's thesis). Yildiz Teknik Universitesi, Istanbul.

Cevikbas, M. (2019). Ters-yuz sinif modeli uygulamalarina dayali bir matematik sinifindaki ogrenci katilim surecinin incelenmesi (Unpublished doctoral dissertation). Gazi Universitesi, Ankara.

Cukurbasi, B. (2016). Ters yuz edilmis sinif modeli ve lego-logo uygulamalari ile desteklenmis probleme dayali ogretim uygulamalarinin lise ogrencilerinin basari ve motivasyonlarina etkisi (Unpublished doctoral dissertation). Sakarya Universitesi, Sakarya.

Demir, E. (2020). 5. sinif fen bilimleri dersi insan ve cevre unitesinde ters yuz sinif uygulamalarinin cevre bilincine etkisinin incelenmesi (Unpublished master's thesis). Kastamonu Universitesi, Kastamonu.

Demiralay Yigit, R. (2014). Evde ders okulda odev modelinin benimsenmesi surecinin yeniligin yayilimi kurami cercevesinde incelenmesi (Unpublished doctoral dissertation). Gazi Universitesi, Ankara.

Demirel, O. (2012). Egitimde program gelistirme, kuramdan uygulamaya. (19th ed.) Ankara: Pegem A.

Demiralay, R. \& Karatas, S. (2014). Evde ders okulda odev modeli. Egitim ve Ogretim Arastirmalari Dergisi, 3(3), 333-340.

Dincer, N. (2020). Ters-yuz edilmis ogrenim modelinin ingilizceyi yabanci dil olarak ogrenen ogrencilerin dilbilgisi yeterliligi ve ogrenen ozerkligi uzerine etkileri (Unpublished master's thesis). Bahcesehir Universitesi, Istanbul.

Donmez, F. I. (2017). Ogretim elemanlarinin web 2.0 teknolojileri kullanimlarina yonelik tersine mesleki gelisim programinin tasarlanmasi ve uygulanmasi (Unpublished doctoral dissertation). Ankara Universitesi, Ankara.

$\mathrm{Du}, \mathrm{Y}$. (2020). Study on cultivating college students' english autonomous learning ability under the flipped classroom model. English Language Teaching, 13(6), 13-19. doi: 10.5539/elt.v13n6p13

Ekmekci, E. (2014). Harmanlanmis ogrenme odakli tersten yapilandirilmis yazma sinifi modeli (Unpublished doctoral dissertation). Gazi Universitesi, Ankara.

Fidan, G. (2019). Besinci sinif bilisim teknolojileri ve yazilim dersi etik ve guvenlik unitesinin ters-yuz ogrenme ve oyunlastirma yaklasimlari ile ogretimi (Unpublished master's thesis). Balikesir Universitesi, Balikesir.

Gencer, B.G., Gurbulak, N. \& Adiguzel, T. (2014). A new approach in learning and teaching, the flipped classroom. In Proceedings of international teacher education conference. 5-7 February 2014 (p. 881888). Dubai, UAE.

Gokdemir, A. \& Gazel, A. A. (2019). Ters yuz ogrenmenin sosyal bilgiler ogretmen adaylarinin yapilandirmaciliga yonelik tutumlarina etkisi. Egitim Kuram ve Uygulama Arastirmalari Dergisi. 5(2), 239-249.

Jdaitawi, M. (2019). The effect of flipped classroom strategy on students learning outcomes. International Journal of Instruction, 12(3), 665-680. doi: 10.29333/iji.2019.12340a

Kaman, N. (2020). Basamaklandirilmis ters yuz ogrenme modeli ogretim surecinin gelistirilmesi (Unpublished master's thesis). Kirsehir Ahi Evran Universitesi, Kirsehir.

Karagoz, M. (2019). Cografya dersi deprem ve yangin afeti konularinin ogretiminde ters yuz edilmis sinif modelinin akademik basariya etkisi (Unpublished master's thesis). Gazi Universitesi, Ankara. 
Kocak, G. (2019). Ters yuz ogrenmenin 7. sinif ogrencilerinin akademik basarisina etkisi (Unpublished master's thesis). Inonu Universitesi, Malatya.

Kokoc, M. \& Altun, A. (2014). Flipped ogrenmeye iliskin sistematik bir alanyazin taramasi: kavramlar ve uygulamalar (Ozet). In Egitim Teknolojisinde Yeni Egilimler Konferansi 14-15 April 2014 (p.35) KKTC: Dogu Akdeniz Universitesi.

Lage, M. J., Platt, G. \& Treglia, M. (2000). Inverting the classroom: A gateway to creating an inclusive learning environment. Journal of Economic Education, 31(1), 30-43. Retrieved 21.04.2020, from https://dl.dropboxusercontent.com/u/249331/Inverted_Classroom_Paper.pdf

Leo, J., \& Puzio, K. (2016). Flipped instruction in a high school science classroom. Journal of Science Education and Technology, 25(5), 775-781. doi: 10.1007/s10956-016-9634-4

Nacaroglu, O. (2020). Ozel yetenekli ogrencilerin ters yuz ogrenme modeline yonelik hazirbulunusluklarinin farkli degiskenler acisindan incelenmesi. Ahi Evran Universitesi Sosyal Bilimler Enstitusu Dergisi (AEUSBED), 6(1), 51-66. doi: 10.31592/aeusbed.661838

Okmen, B. (2020). Basamaklandirilmis ters yuz ogrenme modeli ogretim surecinin gelistirilmesi (Unpublished doctoral dissertation). Duzce Universitesi, Duzce.

Ozaras Oz, G. (2019). Hemsirelik egitiminde ters yuz sinif ogretim yonteminin ogrenci basarisina etkisi (Unpublished doctoral dissertation). Hacettepe Universitesi, Ankara.

Ozbay, O. \& Sarica, R. (2019). Ters yuz sinifa yonelik gerceklestirilen calismalarin egilimleri: bir sistematik alanyazin taramasi. Ahi Evran Universitesi Sosyal Bilimler Enstitusu Dergisi (AEUSBED), 5(2), 332-348. doi: 10.31592/aeusbed.595036

Ozdemir, S. (2019). Ters yuz edilmis sinif modeli ile cift unlulerin sesletiminde dinleme becerilerinin rolu (Unpublished master's thesis). Balikesir Universitesi, Balikesir.

Ritzhaupt, A., \& Sommer, M. (2018). Impact of the fipped classroom on learner achievement and satisfaction in an undergraduate technology literacy course. Journal of Information Technology Education: Research, 17(1), 159-182. doi:10.28945/4059

Saban, A. (2009). Coklu zekâ kurami ile ilgili turkce calismalarin icerik analizi. Kuram ve Uygulamada Egitim Bilimleri, 9(2), 833-876.

Seaman, G. \& Gaines, N. (2013). Leveraging digital learning systems to flip classroom instruction. Modern Teacher Quarterly, 1, 25-27. Retrieved 21.04.2020, from http://modernteacher.com/images/ MTQ.pdf

Secilmisoglu, C. (2019). Ters-yuz egitim modelinin ingilizce dil bilgisi ogretimindeki etkisi (Unpublished master's thesis). Ufuk Universitesi, Ankara.

Sever, G. (2014). Bireysel calgi keman derslerinde cevrilmis ogrenme modelinin uygulanmasi. Egitimde Nitel Arastirmalar Dergisi- Journal of Qualitative Research in Education, 2(2), 27-42.

Sogut, M. (2019). Sosyal Bilgiler 5.sinif etkin vatandaslik ogrenme alaninin ters-yuz sinif modeline gore islenmesinin ogrencilerin akademik basariya etkisi (Unpublished master's thesis). Agri Ibrahim Cecen Universitesi, Agri.

Sogut, M. \& Polat, S. (2020). Ters-yuz sinif modelinin etkin vatandaslik ogrenme alaninin ogretiminde kullanilmasinin ogrencilerin akademik basarilarina etkisi. OPUS-Uluslararasi Toplum Arastirmalari Dergisi, 15(24), 2472-2504. doi: 10.26466/opus.658882

Subramaniam, S. R., \& Muniandy, B. (2019). The effect of flipped classroom on students' engagement. Technology, Knowledge and Learning, 24(3), 355-372. doi:10.1007/s10758-017-9343-y

Sahin, S. (2019). Programlama ogretiminde ters yuz sinif uygulamalarinin ortaokul ogrencilerinin akademik basarisina etkisi (Unpublished master's thesis). Inonu Universitesi, Malatya.

Sik, P. (2019). Ters yuz sinif modelinin cocuklarin kelime ogrenmeleri uzerine etkisi (Unpublished master's thesis). Canakkale Onsekiz Mart Universitesi, Canakkale. 
Tekin, D. (2020). Kimyanin temel kanunlari, kimyasal hesaplamalar ve Mol kavrami unitelerinin yapilandirmacilik temelli ters yuz edilmis sinif modeli ile ogretimi (Unpublished master's thesis). Marmara Universitesi, Istanbul.

Topan, B. (2019). Ters-yuz sinif modeline gore tasarlanan ogrenme ortaminin ortaokul ogrencilerinin istatistik okuryazarlik seviyelerine etkisi (Unpublished doctoral dissertation). Trabzon Universitesi, Trabzon.

Tulay, Z. (2019). Ogrenme merkezli sinif: Ters yuz ogrenmenin yabanci dil olarak Ingilizce ogrenen ogrencilerin dil becerileri ile dijital okuryazarlik uzerindeki etkilerinin ve ogrenme ortamina yonelik davranislarinin arastirilmasi (Unpublished master's thesis). Bahcesehir Universitesi, Istanbul.

Turan, Z. \& Goktas, Y. (2015). Yuksekogretimde yeni bir yaklasim: ogrencilerin ters yuz sinif yontemine iliskin gorusleri. Yuksekogretim ve Bilim Dergisi. 5(2), 156-164. doi: 10.5961/jhes.2015.118

Warren, H. (Ed). (1999). Oxford turkiye sozlugu ingilizce-turkce. (2th ed.). New York: Oxford University Press

Webb, M., \& Doman, E. (2020). Impacts of flipped classrooms on learner attitudes towards technologyenhanced language learning. Computer Assisted Language Learning, 33(3), 240-274. doi: $10.1080 / 09588221.2018 .1557692$

Yildiz, S. N., Sarsar, F., \& Ates Cobanoglu, A. (2017). Donusturulmus sinif uygulamalarinin alanyazina dayali incelenmesi. Elektronik Sosyal Bilimler Dergisi, 16(60), 76-86. doi: 10.17755/esosder.289652

Yildirim, A. \& Simsek, H. (2013). Sosyal bilimlerde nitel arastirma yontemleri (9th ed.). Ankara: Seckin yayincilik

Yilmaz, E. O. (2019). Tartisma odakli tersduz ogrenme ortamlarinin etkililiginin incelenmesi (Unpublished doctoral dissertation). Ankara Universitesi, Ankara. 